\title{
Comprehensive Treatment of Middle Ear Cholesteatoma
}

\author{
Комплексно лечение на холестеатома на средното ухо
}

\author{
Petar Rouev \\ ENT Ward, Trakia Multispecialty Hospital for Active Treatment, Stara Zagora \\ Петър Руев \\ УНГ отделение, МБАЛ „Тракия“ - Стара Загора
}

\begin{abstract}
Summary
Comprehensive treatment of middle ear cholesteatoma involves preoperative treatment, followed by a radical inside-out aticoanthromastoidectomy with cartilage-perichondrium reconstruction of the tympanic membrane. If possible, a reconstruction of the posterior wall of the external auditory canal is done. In all other cases mastoid obliteration with bone pate, cartilage or artificial bone is performed. In case of intact stapes a type III tympanoplasty is performed; in the absence of stapes suprastructures TORP ossicular chain reconstruction is performed when there are no indications for a second-look surgery. Post-operative follow-up of patients includes regular checkups and DW-MRT in some cases.
\end{abstract}

Key words: middle ear cholesteatoma, mastoidectomy, tympanoplasty, residual cholesteatoma

\section{Introduction}

Cholesteatoma is a potentially life-threatening disease due to possible intracranial complications. In addition, due to the duration of the disease, important structures such as auditory ossicles or inner ear can be sacrificed during surgery, but the facial nerve must be preserved. Comparing the principles of cholesteatoma removal surgery with those of tumor surgery, the ENT surgeon's concerns about the upcoming reconstruction may be risky. This would compromise the radicality of cholesteatoma removal and may increase the incidence of disease recurrence.

\section{Резюме}

Комплексното лечение на холестеатома на средното ухо включва предоперативно лечение, последвано от радикална атикоантромастоидектомия в посока отпред-назад с реконструкция на тъпанчевата мембрана с хрущял и перихондриум. При възможност се пристъпва към реконструкция на задната стена на външния слухов проход. В останалите случаи се пристъпва към облитерация на мастоида с костно брашно, хрущял или изкуствена кост. При интактно стреме се извършва III тип тимпанопластика, а при липса на супраструктурите на стремето осикуларната верига се реконструира чрез TORP, когато няма индикации за Second Look операция. Постоперативното проследяване на пациентите включва регулярни прегледи, а в някои случаи и DW-MRT.

Ключови думи: холестеатома на средното ухо, мастоидектомия, тимпанопластика, резидуален холестеатом

\section{Увод}

Холестеатомът е потенциално животозастрашаващо заболяване поради възможните интракраниални усложнения. Освен това, поради продължителността на заболяването, по време на оперативното лечение могат да бъдат жертвани важни структури като слуховите костици или вътрешното ухо, но лицевият нерв трябва да бъде запазен. Сравнявайки принципите на хирургията при отстраняването на холестеатома с принципите на хирургията при отстраняването на туморите, рисковано е, когато отохирургът има притеснения относно предстоящата реконструкция. Това би довело до компромиси по отношение на радикалността при отстраняването на холестеатома и може да доведе до увеличаване на честотата на рецидивите на заболяването. 
If we study the meta-analyses on the problem of middle ear surgery, we will notice the significantly higher incidence of postoperative residual cholesteatoma when using the ,intact canal wall approach“ compared to the „canal wall down approach“ (1). Another meta-analysis shows that reconstruction of the external auditory canal and / or mastoid cavity obliteration is the best surgical alternative with the lowest percentage of postoperative recurrences or purulence from the ear (2). A third meta-analysis shows that relapses in the treatment of cholesteatoma depend largely on the experience of the surgeon and not so much on the chosen surgical strategy (3).

\section{Aim}

The aim of this study is to analyze our strategy for the treatment of cholesteatoma, noting the most important aspects of treatment and identifying the benefits of multistage treatment of cholesteatoma. Material and Methods

A retrospective study of 176 cholesteatoma surgeries for a period of 4 years and 4 months (between 01.06.2014 and 30.09.2018) performed in TrakiaPark Hospital, Stara Zagora. All surgeries were performed by one surgeon, 106 of them being primary operations $(60.23 \%, \mathrm{n}=176), 49$ - revisions of surgeries, performed in other hospitals (27.84\%, $\mathrm{n}=176)$, while 21 were Second-Look surgeries $(11.93 \%, \mathrm{n}=176)$, i.e the study includes 155 patients, aged 4 to 76 (median age $-35,8$; SD $18,0)$. Patients were observed for a period of 1 to 48 months $(11,34$ months on the average; SD 13,10). Distribution of patients $(\mathrm{n}=155)$ was as follows: males 88 , females 67 ; on the left -78 , on the right - 77; Bellucci's classification: Gr. 1/9(5\%), Gr. 2/37 (21\%), Gr. 3/120 (68\%), Gr. 4/10 (6\%). Our surgical concept is demonstrated on Diagram 1.

\section{Results and Discussion}

The distribution of patients on the basis of cholesteatoma location according to the STAM system is as follows:T/80; $\mathrm{A} / 99 ; \mathrm{M} / 67 ; \mathrm{S} 1 / 27 ; \mathrm{S} 2 / 38$; cholesteatoma staging according to EAONO/JOS is as follows: I/71 (45,81\%), II/41 (26,45\%), III/40 $(25,81 \%)$, IV/3 (1.94\%) (4). The following extracranial complications were observed: facial nerve dehiscence in 31 cases; pre fistula of the lateral semicircular canal (blue lining) in 13 cases; tegmen
Ако погледнем метаанализите по проблема на хирургията на средното ухо, прави впечатление значително по-голямата честота на постоперативните резидуални холестеатоми при прилагането на „intact canal wall approach“ в сравнение с „саnal wall down approach“ (1). Един друг метаанализ показва, че реконструкцията на външния слухов проход и/или облитерацията на мастоидната кухина е най-добрата хирургична алтернатива с най-нисък процент постоперативни рецидиви или гноетечение от ухото (2). Трети метаанализ показва, че рецидивите при лечението на холестеатома зависят предимно от опита на хирурга, а не толкова от избраната оперативна стратегия (3).

\section{Цел}

Целта на настоящото проучване е да анализираме нашата стратегия при лечението на холестеатома, като отбележим най-важните моменти в лечението и определим предимствата на многоетапното оперативно лечение на холестеатома.

\section{Материал и методи}

Ретроспективно проучване на 176 операции при холестеатома за период от 4 години и 4 месеца (между 01.06.2014 и 30.09.2018 г.) в Болница Тракия-Парк, Стара Загора. Всички операции са извършени от един хирург, като 106 от тях са първични операции $(60.23 \%, \mathrm{n}=176), 49$ са ревизии на операции, извършени в други болници (27.84\%, $\mathrm{n}=176)$, a 21 ca Second-Look операции $(11.93 \%, \mathrm{n}=176)$, т.е. касае се за 155 пациенти на възраст от 4 до 76 години (средна възраст 35,8 години; SD 18,0). Пациентите са проследени за период от 1 до 48 месеца (средно 11,34 месеца; $\mathrm{SD} 13,10)$. Разпределението на пациентите (n = 155) е следното: мъже 88, жени 67; в ляво - 78, в дясно 77; Класификация на Bellucci: Gr. 1/9 (5\%), Gr. 2/37 (21\%), Gr. 3/120 (68\%), Gr. 4/10 (6\%).

\section{Резултати и обсъждане}

Разпределението на пациентите според локализацията на холестеатома съобразно STAM системата е следното: Т/80; А/99; M/67; S1/27; $\mathrm{S} 2 / 38$, а стадирането на холестеатома, съгласно EAONO/JOS: I/71 (45,81\%), II/41 (26,45\%), III/40 (25,81\%), IV/3 (1.94\%) (4). Наблюдавали сме следните екстракраниални усложнения: дехисценция на лицевия нерв при 31 случая; 


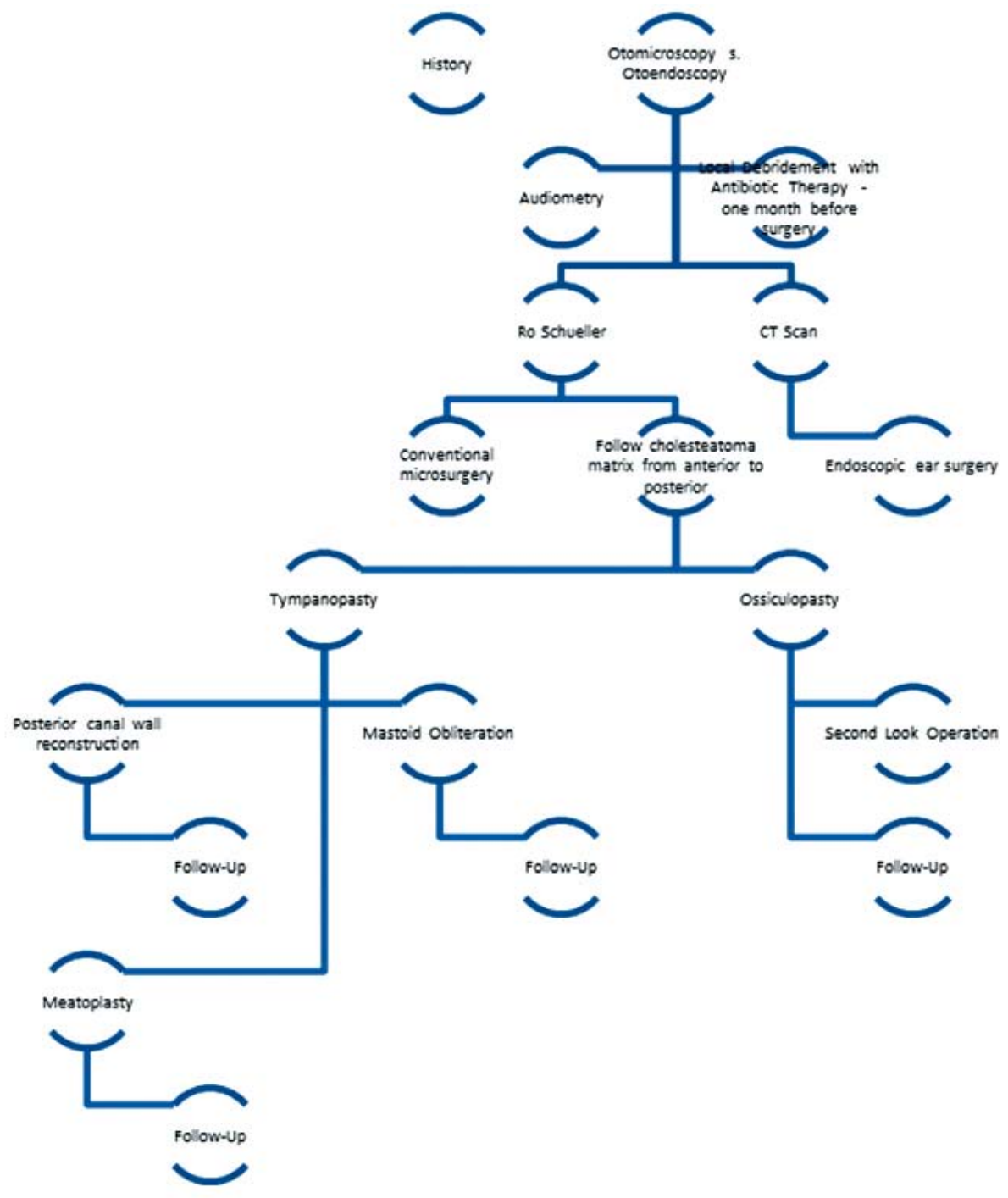

Diagram 1. Algorithm for complex treatment of middle cholesteatoma

Диаграма 1. Алгоритъм на комплексното лечение на холестеатома на средното ухо

tympani et antri defect with presentation of dura matter (21 cases) or with presentation of sinus sigmoideus (5 cases), that do not require recovery; the intracranial complications were as follows: defect of the tegmen tympani et antri with oto liquorrhea, requiring recovery (2 cases) or sinus sigmoideus tamponade ( 1 case).

Otoendoscopy is an additional tool for intraoperative examination in certain areas that cannot be directly inspected with the microscope. For example, an otoendoscope examination in the S1 and S2 area (STAM System) can demonstrate the presence of residual cholesteatoma, which can be removed without further removal of bone structures (4). In our patient group, prevalence in the mastoid cavity is found in just over $50 \%$ of cases, suggest- префистула на латералния полуокръжен канал (синьо просветляване) при 13 случая; дефект на tegmen tympani et antri с представяне на dura matter (21 случая) или с представяне на sinus sigmoideus (5 случая), които не изискват възстановяване, и следните интракраниални усложнения: дефект на tegmen tympani et antri с отоликворея, изискващи възстановяване (2 случая) или тампонада на sinus sigmoideus (1 случай).

Отоендоскопията е допълнителен инструмент за интраоперативно изследване в определени зони, които с помощта на микроскоп не могат да бъдат директно инспектирани. Така например инспекцията с отоендоскоп в S1 и S2 зоната (STAM System) може да докаже наличието на остатъчен холестеатом, който може да бъде отстранен без допълнително премахване на 
ing that nearly half of cases with cholesteatoma in the middle ear can be operated endoscopically. Probably in the future, cholesteatoma surgery will always start endoscopically and, if necessary, the surgeon will proceed with microscopic surgery; or after computed axial tomography of the temporal bone, decisions will be made for a particular type of surgery.

Second-Look surgery was indicated intraoperatively in 56 of 155 cholesteatoma surgeries $(36.13 \%)$. During the study period only 21 Second-Look surgeries were performed $(37.5 \%, \mathrm{n}=56) .9$ of these 21 Second-Look surgeries $(42.86 \%)$ had residual cholesteatoma. In 3 of these 9 cases of residual cholesteatoma an intraoperative indication for a „new Second-Look surgery“ (14.29\%, n = 21) 18 months later was made; in the other 6 cases small cholesteatomic pearls were found, which were completely removed during the intervention. In 11 Second-Look surgeries $(57,14 \%, \mathrm{n}=21)$ type III tympanoplasty was additionally performed with good functional (audiological) results. Ten of them had TORP with dimensions of 3.0 up to $4.75 \mathrm{~mm}$ (mean 3.68; SD 0.57) and air-bone gap (ABG) below $20 \mathrm{~dB}$ in $74 \%$ of the cases; one had PORP with dimensions of $2.5 \mathrm{~mm}$ and air-bone gap (ABG) below $15 \mathrm{~dB}$. A number of authors report better audiological results in cases of two-stage TORP reconstructions $(5,6)$. For the reconstruction we used a wide plate of thinned cartilage $(0.5$ $\mathrm{mm}$ ), which was also used to cover the prosthesis with the aim of preventing its extrusion; in order to prevent prosthesis luxation we slightly increased its length with0.25-0.5 $\mathrm{mm}$ (7), i.e. when measuring the required length of the prosthesis, we rounded it up to the larger size.

Residual cholesteatoma was intraoperatively established in only 5 cases $(3.22 \%, \mathrm{n}=155)$, leaving the mastoid cavity open in these cases. In 3 of these 5 cases it was a secondary operation (the previous one had been performed in another clinic) and in all 5 cases the residual cholesteatoma was found near the facial nerve in the S1 / S2 region. As noted above, another 9 residual cholesteatoma костни структури (4). В нашата група пациенти при малко над 50\% от случаите се установява разпространение към мастоидната кухина, което ни навежда на мисълта, че близо половината от случаите с холестеатом на средното ухо могат да бъдат оперирани по ендоскопски път. Вероятно в бъдеще хирургията на холестеатома ще започва винаги ендоскопски и при необходимост ще конвертира към микроскопска хирургия или след компютърна аксиална томография на темпоралната кост ще се взема решение за даден вид хирургия.

Second-Look операция е индицирана интраоперативно при 56 от 155 операции на холестеатома (36.13\%). През периода на проучването са извършени само 21 Second-Look операции (37.5\%, $\mathrm{n}=56$ ). При 9 от тези 21 Second-Look операции $(42.86 \%)$ са установени резидуални холестеатоми. При 3 от тези 9 случая на резидуален холестеатом интраоперативно отново е поставена индикация за „нова Second-Look операция“ $(14.29 \%, \mathrm{n}=21) 18$ месеца по-късно; при останалите 6 случая са установени малки холестеатомни перли, които са премахнати напълно при интервенцията. При 11 Second-Look операции $(57,14 \%, \mathrm{n}=21)$ допълнително е извършена тимпанопластика III тип с добри функционални (аудиологични) резултати. Десет от тях са с TORP с размери от 3.0 до $4.75 \mathrm{~mm}$ (средно 3.68; $\mathrm{SD} 0.57)$ и въздушно-костна разлика (ABG) под $20 \mathrm{~dB}$ в 74\% от случаите, и един случай с PORP с размер $2.5 \mathrm{~mm}$ и въздушно-костна разлика (ABG) под $15 \mathrm{~dB}$. Редица автори споменават за по-добри аудиологични резултати в случаите с двуетапни TORP реконструкции $(5,6)$. За реконструкция ние използваме широка плочка от изтьнен хрущял $(0.5 \mathrm{~mm})$, която служи и за покриване на протезата, с оглед превенцията на нейната екструзия, а за превенция на луксацията на протезата ние увеличаваме малко дължината на протезата с $0.25-0.5 \mathrm{~mm}$ (7), т.е. при измерването на необходимата дължина на протезата закрьгляме към по-големия размер.

Резидуални холестеатоми интраоперативно установяваме само при 5 случая $(3,22 \%, \mathrm{n}=$ $155)$, като при тези случаи оставяме мастоидната кухина отворена. При 3 от тези 5 случая се касае за вторична операция (предишната е била извършена в друга клиника), а при всичките 5 случая остатъчният холестеатом е бил установен в близост до лицевия нерв в $\mathrm{S} 1 / \mathrm{S} 2$ региона. 
were identified in 21 Second-Look surgeries in the following middle ear areas T / 1, S2 / 1, A / 3, S1 / 4 , or overall we have $9.03 \%(14 ; n=155)$ residual cholesteatoma over the entire study period.

Intraoperative assessment of the auditory ossicles is determined by the Austin-Kartush classification: 0/3 (1.94\%), A/67 (43.23\%), B/27 (17.42\%), C/17 (10.97\%), D/37 (23.87\%), F/4 (2.58\%). The best audiological reconstruction results were obtained in Group A patients, who had preserved malleus handle and preserved and flexible stapes. The preserved malleus handle (62.58\% of the cases: $97 ; n$ $=155$ ) is a prerequisite for the reconstruction to be performed on the plane of the original tympanic membrane, while the presence of preserved and flexible stapes $(56.13 \%$ of the cases: $87 ; n=155)$ creates conditions to perform type III tympanoplasty $(46.45 \%$ of the cases: $72 ; n=155)$. We have to stress the fact that preservation of the incus was performed in only three cases $(1.94 \%$ of the cases: $3 ; \mathrm{n}=155)$. As in most cases of cholesteatoma surgery, the inspection of the anterior epitympanum is associated with removal of the malleus head, the preservation of the incus becomes meaningless. The most unfavourable cases from an audiological point of view are those in which only the stapes plate is found $(43.87 \%$ of the cases: $68 ; n=155)$, or those with stapes plate fixation $(2.58 \%$ of the cases: $4 ; n=155)$. They are also the most complicated cases from a surgical point of view, summarized under the term ,stapes plate instability“(8). In addition, these cases are further complicated by the possibility of inner ear infection. In such cases reconstruction of the stapes plate with a cartilage or fascia is obligatory (9).

When reconstruction of auditory ossicles was not possible, we only performed reconstruction of the tympanic membrane, i.e. type I tympanoplasty in $36.77 \%$ of the cases $(57 ; n=155)$. Reconstruction of the posterior wall of the external auditory canal was performed in $51.61 \%$ of the cases $(80 ; n=155)$. Mastoid obliteration was done when reconstruction of the external auditory canal was not possible (65, $41.94 \% ; n=155)$. In most cases we used cartilage $(68 \%)$, or bone pate (BonePate, $74 \%$ ), while artificial bone (BonAlive) was used in only $25 \%$ of the
Както отбелязхме по-горе, други 9 остатьчни холестеатоми са установени при 21 SecondLook операции в следните зони на средното ухо $\mathrm{T} / 1, \mathrm{~S} 2 / 1, \mathrm{~A} / 3, \mathrm{~S} 1 / 4$, или като цяло имаме $9.03 \%$ $(14 ; \mathrm{n}=155)$ резидуален холестеатом за целия период на проучването.

Интраоперативно оценката на състоянието на слуховата верига определяме по Класификацията на Austin-Kartush: 0/3 (1.94\%), A/67 (43.23\%), B/27 (17.42\%), C/17 (10.97\%), D/37 (23.87\%), F/4 $(2.58 \%)$. Най-добри аудиологични резултати от реконструкцията се получават при пациентите от група A, при които има запазена дръжка на чукчето и запазено и подвижно стреме. Запазената дръжка на чукчето (62.58\% от случаите: $97 ; n=155)$ е предпоставка реконструкцията да бъде извършена на равнината на оригиналната тьпанчева мембрана, а наличието на запазено и подвижно стреме (56.13\% от случаите: 87 ; $\mathrm{n}=155)$ създава условия за извършване на III тип тимпанопластика (46.45\% от случаите: 72 ; $\mathrm{n}=155)$. Държим да отбележим, че само в три случая при хирургия на холестеатома имаме запазване на наковалнята (1.94\% от случаите: 3 ; $\mathrm{n}=155)$. Тъй като в повечето случаи при хирургия на холестеатома инспекцията на предния епитимпанум е свързана с премахване на главичката на чукчето, се обезсмисля запазването на наковалнята. Най-неблагоприятните от аудиологична гледна точка случаи са тези, при които се установява само плочка на стремето $(43.87 \%$ от случаите: $68 ; \mathrm{n}=155)$ или в случаите с фиксация на плочката на стремето (2.58\% от случаите: 4 ; $\mathrm{n}=155)$. Те са и най-комплицираните в хирургичен план случаи, обобщени с понятието „нестабилност на плочката на стремето“ (8). Освен това тези случаи са комплицирани и от възможността за проникване на инфекция към вътрешното ухо. Тук е задължителна реконструкцията на плочката на стремето с хрущял или с фасция (9).

Когато няма възможност за реконструкция на слуховата верига, извьршваме реконструкция само на тъпанчевата мембрана, т.е. тимпанопластика I тип имаме при $36.77 \%$ от случаите $(57 ; n=155)$. Реконструкцията на задната стена на външния слухов проход имаме при $51.61 \%$ от случаите $(80 ; \mathrm{n}=155)$. При невъ3можност за реконструкция на външния слухов проход извършваме облитерация на мастоида $(65,41.94 \% ; \mathrm{n}=155)$. В най-голям процент от случаите използваме хрущял $(68 \%)$ или костно 
cases. Mastoid obliteration was performed in both primary surgery and revision interventions. The difference lies in the frequency of mastoid obliteration in primary and subsequent interventions - in revision surgeries we had obliteration in $79.59 \%$ $(39 ; \mathrm{n}=49)$, while in primary surgeries they were performed in only $24.53 \%(26, \mathrm{n}=106)$.

Postoperative complications occurred in 17 cases $(10,97 \% ; n=155)$, including infection - 6; granulation -4 ; retraction pocket -2 ; open vestibulum or labyrinthitis (Vertigo and SNHL) - 6; oto-liquorrhea -1 ; facial nerve dysfunction -3 . Of all 17 patients with complications only 8 of them $(5.16 \%$; $\mathrm{n}=155)$ had persistent complications after the treatment. Because cholesteatoma operations are successful in terms of infection, even in untreated cases, postoperative complications today are relatively rare. In this connection, the most important is the symptom of dizziness, which, despite the treatment, or as a result of it, can persist, in which cases this symptom has the largest role in determining the quality of life in patients who have undergone complex treatment.

However, cholesteatoma surgery is essentially a facial nerve surgery. The best way to avoid facial nerve damage during the operation is to identify it as early as possible. Besides the ratios between the individual structures of the middle ear, in most cases indirect indication as to its location is the operative reaching of its perineural vascular plexus. Patients with middle ear cholesteatoma are prone to facial nerve damage, the tympanic segment being most frequently affected. We find greater damaging potential in cases where the stapes suprastuctures are absent. Therefore, in such cases, the ENT surgeon should perform the dissection carefully, especially when preoperative evidence of damage of the stapes suprastuctures is available. (10). брашно (BonePate, 74\%), а изкуствена кост сме използвали (BonAlive) само в $25 \%$ от случаите. Облитерация на мастоида извършваме както при първична хирургия, така и при ревизионни интервенции. Разликата е в честотата на облитерация на мастоида при пьрвичните и при последващите оперативни интервенции, така при ре-операциите имаме облитерация в $79.59 \%$ $(39 ; \mathrm{n}=49)$, докато при първичните операции те са само в $24.53 \%(26, \mathrm{n}=106)$.

Постоперативни усложнения имаме при 17 случая $(10,97 \% ; \mathrm{n}=155)$, в това число инфекция - 6; гранулации - 4; ретракционен джоб 2 ; отворен вестибулум или лабиринтит (Vertigo и SNHL) - 6; отоликворея - 1; дисфункция на лицевия нерв- 3. От всички тези 17 пациенти с усложнения само при 8 от случаите $(5.16 \%$; $\mathrm{n}=155)$ усложненията персистират след проведеното лечение. Тъй като операциите при холестеатом са успешни по отношение на инфекцията дори и при нелекуваните случаи, днес постоперативните усложнения са относително редки. В тази връзка най-важен се явява симптомът световъртеж, който въпреки проведеното лечение или следствие на него може да персистира, като в тези случаи този симптом има най-голям дял в определяне на качеството на живот при пациентите, провели комплексно лечение.

В същността си обаче хирургията на холестеатома е хирургия на лицевия нерв. Най-добрият начин да се избегне увреждането му в хода на операцията е да бъде идентифициран възможно най-рано. Освен съотношенията между отделните структури на средното ухо най-често индиректен ориентир за разположението му интраоперативно е достигането на периневралния му съдов плексус. Пациентите с холестеатом на средното ухо са предразположени към увреждане на лицевия нерв, като най-често той се засяга в тимпаналния сегмент. Ние установяваме по-голям потенциал за увреждането му при липса на супраструктурите на стремето. Следователно в тези случаи отохирургът би следвало да извършва дисекцията внимателно, особено когато са налице предоперативни данни за увреда на супраструктурите на стремето (10). 


\section{Conclusion}

Regardless of the severity, prevalence and duration of the disease, the presence of previous operations, the method of choice in the treatment of cholesteatoma is a one-stage „Canal Wall Down“ mastoidectomy with reconstruction of the posterior wall of the external auditory canal and type III tympanoplasty in cases of preserved and mobile stapes. If reconstruction of the posterior wall of the external auditory canal is not possible, mastoid obliteration is a safe and effective method of rehabilitation of CWD mastoidectomies, since, on the one hand, mastoid obliteration is a procedure well tolerated by patients, and on the other side, it can be applied not only for revision surgeries, but also for the initial surgical treatment of the cholesteatoma. In cases of posterior wall reconstruction with or without additional mastoid obliteration, or in cases with mastoid cavity obliteration only, we no longer speak about an open or closed cholesteatoma technique but define it as an ,individualized approach“ or an ,adapted technique“ (11).

At the present stage of medical development, cholesteatoma removal is possible in a large percentage of cases. Several surgical interventions may need to be performed, and the long-term perspective of these patients depends on many factors. Therefore, they need to be monitored for many years. The recurrence of the disease may occur long after the first operative intervention. Perform annual checkups, including in asymptomatic patients. In order to reduce recurrent and residual cholesteatoma, the most important part of its complex treatment is the use of cartilage for reconstruction on the one hand, and on the other - the decision at the end of surgery for the need of Second-Look surgery. In addition, for better audiological results, additional ossiculoplasty is most often performed with this Second-Look operation. Functional audiological results after cholesteatoma surgery are varying but there exists the possibility of hearing aids or hearing device implantation.

\section{Заключение}

Независимо от тежестта, разпространението и продължителността на заболяването, наличието на предшестващи операции метод на избор при лечението на холестеатома е едноетапната „Canal Wall Down“ мастоидектомия с реконструкция на задната стена на външния слухов проход и тимпанопластика III тип, при запазено и подвижно стреме. Ако реконструкцията на задната стена на външния слухов проход не е възможна, облитерацията на мастоида е сигурен и ефективен метод за рехабилитация на CWD мастоидектомиите, тъй като, от една страна, облитерацията на мастоида е процедура, която много добре се понася от пациентите, а от друга страна - може да бъде прилагана не само при ревизиращи операции, но и при инициалното хирургично лечение на холестеатома. В случаите с реконструкция на задната стена със или без допълнителна облитерация на мастоида или в случаите само с облитерация на мастоидната кухина вече не говорим за отворена или затворена техника при холестеатома, а за „индивидуализиран подход“ или „адаптирана техника“ (11).

На сегашния етап на развитие на медицината отстраняването на холестеатома е възможно в големия процент от случаите. При това може да се наложи да се извършат няколко оперативни интервенции, като дългосрочната перспектива на тези пациенти зависи от множество фактори. Затова е необходимо те да бъдат наблюдавани в течение на много години. Повторната поява на заболяването може да се получи дълго време след първата оперативна интервенция. Предвиждайте ежегодни контролни прегледи, включително и при асимптоматичните пациенти. C оглед намаляване на повторния и остатъчния холестеатом най-важната част от комплексното му лечение е използването на хрущял за реконструкция, от една страна, а от друга - решението в края на операцията за необходимостта от Second-Look операция. Освен това с оглед на по-добрите аудиологични резултати най-често заедно с тази Second-Look операция се извършва и допълнителна осикулопластика. Функционалните аудиологични резултати след хирургия на холестеатома са променливи, но с възможност за слухопротезиране или имплантиране. 


\section{Reference/Литература}

1. Tomlin J et al., Surgical technique and recurrence in cholesteatoma: a meta-analysis. Audiol Neurotol 2013; 18: 135-142.

2. Harris AT et al., Pooled analysis of the evidence for open cavity, combined approach and reconstruction of the mastoid cavity in primary cholesteatoma surgery. The Journal of Laryngology \& Otology 2016; 130(3): 235-241.

3. Neudert M et al., Cholesteatoma Recidivism: Comparison of Three Different Surgical Techniques. Otology \& Neurotology 2014; 35(10): $1801-8$.

4. Matthew Yung et al. EAONO/JOS Joint Consensus Statements on the Definitions, Classification and Staging of Middle Ear Cholesteatoma, J Int Adv Otol 2017 • DOI: $10.5152 /$ iao.2017.3363

5. Joao Martins, Helder Silva, Victor Certal, Hugo Amorim, Carlos Carvalho et al., Ossiculoplasty With Titanium Prosthesis. Acta Otorrinolaringologica (English Edition) Volume 62, Issue 4, July-August 2011, Pages 295-299.

6. NICOLA QUARANTA, STEFANIA ZIZZI \& ANTONIO QUARANTA, Hearing results using titanium ossicular replacement prosthesis in intact canal wall tympanoplasty for cholesteatoma. Acta Oto-Laryngologica, 2010; Early Online, 1-5.

7. Nguyen DQ, Morel ND, Troussier J, Lavieille JP, Schmerber S. Ossiculoplasty with KURZ titanium prosthesis. Ann Otolaryngol Chir Cervicofac 2005; 122: 187- 93.

8. JC Lüers, D Schwarz, K Stürmer, KB Hüttenbrink. Titan-TORPs 15 Jahre nach der Implantation - was passiert im Bereich der Stapesfußplatte? Laryngo-Rhino-Otol 2018; 97(S 02): S218 DOI: 10.1055/s-0038-1640468

9. Martin Bremke, Karl-Bernd Hüttenbrink, Dirk Beutner. The sandwich cartilage shoe technique for ossicular reconstruction in a case of an unsecure stapes footplate. The Laryngoscope Volume121, Issue9 September 2011 Pages 1950-1952

10. N W C Chee, T Y Tan, The Value of Pre-operative High Resolution CT Scans in Cholesteatoma Surgery. Singapore Med J 2001 Vol 42(4): $155-159$.

11. H. Hildamann et al., 2004; In: Middle Ear Surgery: Recent Advances and Future Directions, K. Jahke (Ed.) 